\title{
Kadar Antibodi Campak pada Anak Usia 1-4 Tahun Pasca Imunisasi Campak
}

Arie Dian Fatmawati, Mulya R. Karyanti, Hartono Gunardi, Arwin A.P. Akib, Darmawan B. Setyanto, Rismala Dewi

Departemen Ilmu Kesehatan Anak Fakultas Kedokteran Universitas Indonesia Rumah Sakit Dr. Cipto Mangunkusumo, Jakarta

Latar belakang. Belum ada penelitian di Indonesia yang membandingkan kadar antibodi campak pada anak usia 1-4 tahun, setelah imunisasi campak 1 kali dibanding 2 kali.

Tujuan. Menganalisis apakah kadar antibodi campak setelah pemberian imunisasi campak 2 kali mencapai kadar protektif dibanding imunisasi campak 1 kali.

Metode. Penelitian potong lintang di 6 posyandu di 5 wilayah DKI Jakarta pada Juni - Agustus 2014. Anak yang memenuhi kriteria inklusi diperiksa kadar IgG campak, dievaluasi dan dilakukan uji korelasi untuk menilai hubungan antara imunisasi campak dosis ke-2 dengan kadar antibodi campak.

Hasil. Dari 145 subjek penelitian, 125 subjek $(86,2 \%)$ memiliki kadar antibodi campak mencapai kadar protektif ( $\geq 120$ mIU/ ml). Kelompok usia 3-4 tahun memiliki kadar antibodi campak yang mencapai kadar protektif terbanyak yaitu 56 subjek (91,8\%) dibanding kelompok usia lainnya.

Kesimpulan. Pemberian imunisasi campak 2 kali meningkatkan antibodi campak yang mencapai kadar protektif sebesar 1,2 kali dibanding pemberian imunisasi campak 1 kali. Sari Pediatri 2018;20(1):43-9

Kata kunci: imunisasi campak, kadar antibodi campak, anak usia 1-4 tahun

\section{Measles Antibody Level in Children 1-4 Years Old after Measles Immunization}

Arie Dian Fatmawati, Mulya R. Karyanti, Hartono Gunardi, Arwin A.P. Akib, Darmawan B. Setyanto, Rismala Dewi

Background. There has been no research yet in Indonesia which compare measles antibody level developed in children 1-4 years old, after once compared to twice measles immunization.

Objectives. To study whether measles antibody level after 2 doses compared to 1 dose of measles immunization reached protective level. Methods. Cross-sectional study performed in 6 posyandu in 5 region of Jakarta from June until August 2014. Children who met the inclusion criteria were measured for measles IgG and performed of correlation test to evaluate the association between second dose of measles immunization with measles antibody level.

Results. From 145 participants, 125 (86,2\%) had protective measles antibody level ( $\geq 120 \mathrm{mIU} / \mathrm{ml})$. Children in 3-4 years old group had highest percentage of protective measles antibody level $(91,8 \% ; 56$ subjects) compare to the other group.

Conclusion. Twice measles immunization will increase protective level of measles antibody 1,2 times compare to once measles immunization. Sari Pediatri 2018;20(1):43-9

Keywords: measles immunization, measles antibody level, children 1-4 years old

Alamat korespondensi: Arie Dian Fatmawati. Departemen Ilmu Kesehatan Anak Fakultas Kedokteran Universitas Indonesia Rumah Sakit Dr. Cipto Mangunkusumo, Jakarta. Email: drariedian@gmail.com 
Arie Dian Fatmawati dkk: Kadar antibodi campak pada anak usia 1-4 tahun pasca imunisasi campak

$\mathrm{P}$ enyakit campak masih banyak ditemui di beberapa negara berkembang, terutama di negara Asia dan Afrika. Data World Health Organization (WHO) menunjukkan angka kematian akibat campak di dunia sebanyak 164.000 pada tahun 2008 dan 158.000 pada tahun 2011. Indonesia termasuk salah satu dari 47 negara penyumbang kasus campak terbesar di dunia. ${ }^{1,2}$

Campak berpotensi menimbulkan kejadian luar biasa (KLB) dengan angka kematian yang tinggi. ${ }^{3-5}$ Prevalensi campak di Indonesia dari tahun 2008-2012 cenderung turun, tetapi KLB masih sering ditemukan. ${ }^{6}$ Pelaksanaan imunisasi campak di Indonesia tahun 1984, cakupan imunisasi campak 12,7\%. Cakupan ini meningkat $85,4 \%$ pada 1990 dan $91,8 \%$ pada 2004 . Namun, dengan pertimbangan angka serokonversi 85\% (antibodi yang terdeteksi dalam serum akibat infeksi atau imunisasi) pada bayi umur 9 bulan, cakupan imunisasi $91,8 \%$ pada tahun 2004 hanya dapat melindungi $76,5 \%$ bayi; $23,5 \%$ lainnya termasuk dalam kelompok rentan campak. Kelompok rentan ini akan terus terakumulasi dan berisiko mengakibatkan KLB campak. Oleh karena itu, diperlukan intervensi imunisasi campak tambahan pada anak balita. ${ }^{4,7} 8$ Pada umumnya, KLB yang terjadi di beberapa provinsi menunjukkan kasus tertinggi pada golongan usia 1-4 tahun. ${ }^{9-11}$

Badan Kesehatan dunia WHO merekomendasikan pemberian vaksin campak 2 dosis, terutama di negara endemis campak, karena $15 \%$ anak yang divaksinasi dengan 1 dosis gagal mempertahankan imunitasnya. ${ }^{1}$ Untuk menciptakan visi "dunia tanpa campak" seperti tertuang dalam Global Measles and Rubella Strategic Plan 2012-2020 yang didukung oleh WHO dan United Nations of Children's Fund $(\mathrm{UNICEF})^{12}$ maka Kementerian Kesehatan Republik Indonesia mengeluarkan Peraturan Menteri Kesehatan (Permenkes) RI No. 42 tahun 2013 mengenai pemberian imunisasi campak ke-2 pada usia 2 tahun, ${ }^{13}$ terutama pada anak yang belum mendapatkan imunisasi MMR pada usia 15-18 bulan. ${ }^{14}$ Pemberian imunisasi campak 2 kali diharapkan dapat meningkatkan seroprotektif terhadap campak. Namun, sejauh ini belum ada publikasi penelitian tentang peningkatan kadar antibodi campak setelah imunisasi campak 2 dosis pada anak Indonesia.

Penelitian ini bertujuan untuk menganalisis apakah kadar antibodi campak setelah pemberian vaksinasi campak 2 dosis (usia 9-12 bulan dan usia 2 tahun) mencapai kadar protektif.

\section{Metode}

Penelitian potong lintang analitik ini dilakukan pada bulan Juni-Agustus 2014 di 6 Pos Pelayanan Terpadu (Posyandu) pada 5 wilayah DKI Jakarta. Subjek penelitian adalah anak sehat berusia 1-4 tahun yang telah diimunisasi campak 1 kali atau 2 kali. Rekrutmen subjek dilakukan secara consecutive sampling dengan kriteria eksklusi, yaitu anak yang sudah pernah sakit campak atau anak dengan kondisi imunosupresi (pemakaian steroid $>14$ hari, menderita keganasan, penyakit autoimun).

Anak yang memenuhi kriteria inklusi diambil darah $3 \mathrm{ml}$ oleh petugas laboratorium klinik Prodia dan diperiksa kadar antibodi (IgG) terhadap campak dengan metode ELISA. Reagen kit yang digunakan adalah kit produk Euroimmun $A G, D-23560$, Lubeck, Germany, Cat: EI2610-9601G, Lot: E140325CA. The WHO Expert Committee on Biological Standardization saat ini menyatakan penggunaan Third International Reference serum untuk menyatakan kadar antibodi campak yang protektif yaitu $\geq 120 \mathrm{mIU} / \mathrm{ml} .{ }^{15}$

Penelitian ini disetujui oleh Komite Etik Penelitian Kesehatan FKUI (Surat Keterangan Lolos Kaji Etik nomor 712/H2.F1/ETIK/2013 tertanggal 18 November 2013). Data yang terkumpul diolah menggunakan SPSS versi 17.0. Analisis bivariat untuk mencari hubungan antara usia saat diperiksa kadar antibodi campak, usia saat imunisasi, status gizi, kondisi kesehatan saat imunisasi campak, dan frekuensi imunisasi campak dengan kadar antibodi protektif terhadap campak dilakukan dengan metode Kai kuadrat $\left(\mathrm{X}^{2}\right)$. Jika tidak memenuhi syarat uji Kai kuadrat maka dilakukan uji Fisher maupun penggabungan sel.

\section{Hasil}

Terdapat 159 anak yang memenuhi kriteria inklusi. Terjadi drop-out pada tiga subjek, dua subjek menolak pengambilan darah dan satu volume darah subjek tidak mencukupi untuk analisis antibodi. Dari 156 subjek penelitian yang tersisa, 11 sampel darah subjek mengalami lisis sehingga tidak diikutsertakan dalam penelitian. Total subjek yang dianalisis untuk penelitian adalah 145 subjek. Sebagian besar subjek $(42,1 \%)$ berada pada golongan usia 3-4 tahun, perempuan 
(58,6\%), bergizi baik (63,4\%), dan sehat. Karakteristik subjek penelitian tertera pada Tabel 1 .

Dari 145 subjek, $125(86,2 \%)$ memiliki kadar antibodi campak dengan kadar protektif ( $\geq 120 \mathrm{mIU} /$ ml) dan $20(13,8 \%)$ tidak mencapai kadar protektif $(<120 \mathrm{mIU} / \mathrm{ml})$ (Tabel 2). Distribusi data antibodi campak tidak normal sehingga digunakan median dan nilai minimum maksimum sebagai ukuran penyebaran.

Tabel 1. Karakteristik Subjek

\begin{tabular}{|c|c|c|}
\hline Karakteristik & Jumlah $(\mathrm{n}=145)$ & Persentase $(\%)$ \\
\hline \multicolumn{3}{|l|}{ Usia (tahun) } \\
\hline $1-<2$ & 33 & 22,8 \\
\hline $2-<3$ & 51 & 35,2 \\
\hline $3-4$ & 61 & 42,1 \\
\hline \multicolumn{3}{|l|}{ Jenis kelamin } \\
\hline Lelaki & 60 & 41,4 \\
\hline Perempuan & 85 & 58,6 \\
\hline \multicolumn{3}{|l|}{ Status gizi } \\
\hline Baik & 92 & 63,4 \\
\hline Kurang & 19 & 13,1 \\
\hline Buruk & 9 & 6,2 \\
\hline Lebih & 25 & 17,2 \\
\hline \multicolumn{3}{|c|}{ Frekuensi imunisasi campak } \\
\hline 1 kali & 95 & 65,5 \\
\hline 2 kali & 50 & 34,5 \\
\hline \multicolumn{3}{|c|}{ Usia imunisasi campak pertama (bulan) } \\
\hline 9 & 110 & 75,9 \\
\hline 10 & 21 & 14,5 \\
\hline 11 & 2 & 1,4 \\
\hline 12 & 6 & 4,1 \\
\hline$>12$ & 6 & 4,1 \\
\hline \multicolumn{3}{|c|}{ Usia imunisasi campak ke-dua (tahun) } \\
\hline 2 & 22 & 44 \\
\hline 3 & 18 & 36 \\
\hline 4 & 10 & 20 \\
\hline \multicolumn{3}{|c|}{ Tempat mendapatkan imunisasi campak pertama } \\
\hline Posyandu & 26 & 17,9 \\
\hline Puskesmas & 69 & 47,6 \\
\hline Klinik umum & 6 & 4,1 \\
\hline Rumah bersalin & 41 & 28,3 \\
\hline Rumah sakit & 3 & 2,1 \\
\hline \multicolumn{3}{|c|}{ Tempat mendapatkan imunisasi campak kedua } \\
\hline Posyandu & 45 & 90 \\
\hline Puskesmas & 5 & 10 \\
\hline \multicolumn{3}{|c|}{ Petugas kesehatan yang memberikan imunisasi campak pertama } \\
\hline Perawat/bidan & 139 & 95,9 \\
\hline Dokter umum & 6 & 4,1 \\
\hline \multicolumn{3}{|c|}{ Petugas kesehatan yang memberikan imunisasi campak kedua } \\
\hline Perawat/bidan & 50 & 100 \\
\hline
\end{tabular}


Arie Dian Fatmawati dkk: Kadar antibodi campak pada anak usia 1-4 tahun pasca imunisasi campak

\begin{tabular}{lcc}
\hline Karakteristik & Jumlah $(\mathrm{n}=145)$ & Persentase $(\%)$ \\
\hline Anggota tubuh yang disuntik saat imunisasi campak pertama & & \\
$\quad$ Deltoid & 75 & 51,7 \\
Paha anterolateral & 70 & 48,3 \\
Anggota tubuh yang disuntik saat imunisasi campak kedua & & \\
$\quad$ Deltoid & 48 & 96,0 \\
Paha anterolateral & 2 & 4,0 \\
Tingkat sosial ekonomi & & \\
Rendah & 15 & 10,3 \\
Menengah kebawah & 100 & 69,0 \\
Menengah keatas & 30 & 20,7 \\
Tingkat pendidikan orangtua/wali & & \\
$\quad$ Rendah & 58 & 40 \\
Menengah & 81 & 55,9 \\
Tinggi & 6 & 4,1 \\
\hline
\end{tabular}

Tabel 2. Kadar antibodi campak pada subjek

\begin{tabular}{|c|c|c|}
\hline Karakteristik & $\begin{array}{l}\text { Imunisasi campak } \\
\quad 1 \text { kali }\end{array}$ & $\begin{array}{l}\text { Imunisasi campak } \\
2 \text { kali }\end{array}$ \\
\hline $\begin{array}{l}\text { Median kadar antibodi campak pada } \\
\text { semua subjek }(\mathrm{n}=145) \text {, tahun }\end{array}$ & $792,3 \mathrm{mIU} / \mathrm{ml}(\mathrm{n}=95)$ & $984 \mathrm{mIU} / \mathrm{ml}(\mathrm{n}=50)$ \\
\hline Usia $1-<2$ & $470,5 \mathrm{mIU} / \mathrm{ml}(\mathrm{n}=32)$ & $484 \mathrm{mIU} / \mathrm{ml}(\mathrm{n}=1)$ \\
\hline Usia $2-<3$ & $581 \mathrm{mIU} / \mathrm{ml}(\mathrm{n}=31)$ & $951,5 \mathrm{mIU} / \mathrm{ml}(\mathrm{n}=20)$ \\
\hline Usia $3-4$ & $633 \mathrm{mIU} / \mathrm{ml}(\mathrm{n}=32)$ & $1160 \mathrm{mIU} / \mathrm{ml}(\mathrm{n}=29)$ \\
\hline Proporsi subjek seroprotektif & $76(80 \%)$ & $49(98 \%)$ \\
\hline $\begin{array}{l}\text { Median kadar antibodi campak pada } \\
\text { subjek seroprotektif }(n=125) \text {, tahun }\end{array}$ & $733,5(132-5000) \mathrm{mIU} / \mathrm{ml}$ & $885(129-5000) \mathrm{mIU} / \mathrm{ml}$ \\
\hline Usia $1-<2$ & $737(147-5000) \mathrm{mIU} / \mathrm{ml}(\mathrm{n}=23)$ & $(\mathrm{n}=1)$ \\
\hline Usia $2-<3$ & $672(132-5000) \mathrm{mIU} / \mathrm{ml}(\mathrm{n}=25)$ & $951,5(249-3052) \mathrm{mIU} / \mathrm{ml}(\mathrm{n}=20)$ \\
\hline Usia $3-4$ & $1774,5(240-5000) \mathrm{mIU} / \mathrm{ml}(\mathrm{n}=28)$ & $884,5(129-5000) \mathrm{mIU} / \mathrm{ml}(\mathrm{n}=28)$ \\
\hline $\begin{array}{l}\text { Median interval waktu } \\
\text { usia periksa dengan usia imunisasi pertama } \\
\text { (tahun) }\end{array}$ & $16(3-30)$ bulan & $34(13-50)$ bulan \\
\hline Usia $1-<2$ & $10(3-24)$ bulan & - \\
\hline Usia $2-<3$ & $18(13-27)$ bulan & $22,5(16-38)$ bulan \\
\hline Usia $3-4$ & $28(27-30)$ bulan & $35(25-50)$ bulan \\
\hline $\begin{array}{l}\text { Median interval waktu } \\
\text { usia periksa dengan usia imunisasi kedua } \\
\text { (tahun) }\end{array}$ & - & $10(0-32)$ bulan \\
\hline Usia $1-<2$ & - & - \\
\hline Usia $2-<3$ & - & $8(0-12)$ bulan \\
\hline Usia $3-4$ & - & $13(1-32)$ bulan \\
\hline $\begin{array}{l}\text { Median interval waktu } \\
\text { usia imunisasi pertama dengan usia } \\
\text { imunisasi kedua (tahun) }\end{array}$ & - & $15(3-39)$ bulan \\
\hline Usia $1-<2$ & - & - \\
\hline Usia $2-<3$ & - & 15 (12-27) bulan \\
\hline Usia $3-4$ & - & 26,5 (9-39) bulan \\
\hline
\end{tabular}


Arie Dian Fatmawati dkk: Kadar antibodi campak pada anak usia 1-4 tahun pasca imunisasi campak

Tabel 3. Hubungan usia, usia saat imunisasi campak, dan status gizi terhadap kadar antibodi campak

\begin{tabular}{|c|c|c|c|c|c|}
\hline \multirow[t]{2}{*}{ Karakteristik } & \multicolumn{2}{|c|}{ Protektif } & \multicolumn{2}{|c|}{ Tidak protektif } & \multirow[t]{2}{*}{$\mathrm{p}$} \\
\hline & Jumlah & $(\%)$ & Jumlah & $(\%)$ & \\
\hline \multicolumn{6}{|l|}{ Usia (tahun) } \\
\hline $1-2$ & 24 & 72,7 & 9 & 27,3 & $0,03 *$ \\
\hline $2-3$ & 45 & 88,2 & 6 & 11,7 & \\
\hline $3-4$ & 56 & 91,8 & 5 & 8,2 & \\
\hline \multicolumn{6}{|l|}{ Status gizi } \\
\hline Baik & 104 & 88,8 & 13 & 11,2 & $0,06 * *$ \\
\hline Kurang & 21 & 75 & 7 & 25 & \\
\hline \multicolumn{6}{|c|}{ Usia imunisasi campak pertama (bulan) } \\
\hline 9 & 97 & 88,2 & 13 & 11,8 & $0,26 * *$ \\
\hline$>9$ & 28 & 80 & 7 & 20 & \\
\hline \multicolumn{6}{|c|}{ Usia imunisasi campak kedua (tahun) } \\
\hline 2 & 21 & 95,4 & 1 & 4,6 & $0,44 * *$ \\
\hline $3-4$ & 28 & 100 & 0 & 0 & \\
\hline
\end{tabular}

Tabel 4. Hubungan antara frekuensi imunisasi campak terhadap kadar antibodi campak

\begin{tabular}{|c|c|c|c|c|c|c|c|}
\hline \multirow{2}{*}{\multicolumn{2}{|c|}{ Karakteristik }} & \multicolumn{2}{|c|}{ Protektif } & \multicolumn{2}{|c|}{ Tidak protektif } & \multirow{2}{*}{$\begin{array}{c}\text { Rasio Prevalens } \\
\text { (IK 95\%) }\end{array}$} & \multirow[t]{2}{*}{$\mathrm{p}$} \\
\hline & & Jumlah & Persentase $(\%)$ & Jumlah & Persentase (\%) & & \\
\hline \multirow{2}{*}{$\begin{array}{l}\text { Frekuensi imunisasi } \\
\text { campak }\end{array}$} & 2 kali & 49 & 98 & 1 & 2 & 1,2 & $0,002^{*}$ \\
\hline & $1 \mathrm{kali}$ & 76 & 80 & 19 & 20 & $(1,1-1,4)$ & \\
\hline
\end{tabular}

* uji Kai kuadrat. Dari uji Kai kuadrat didapatkan rasio prevalens 1,2 (IK95\% antara 1,1 sampai 1,4; p=0,002).

Secara keseluruhan, median kadar antibodi campak $753 \mathrm{mIU} / \mathrm{ml}$ dan pada kelompok protektif $844 \mathrm{mIU} /$ $\mathrm{ml}(129-5000 \mathrm{mIU} / \mathrm{ml})$. Berdasarkan karakteristik subjek, hanya usia saat diperiksakan antibodi campak yang memiliki hubungan bermakna (Tabel 3). Kelompok usia 3-4 tahun mencapai kadar protektif terbanyak $(91,8 \%)$ dibanding kelompok 2-3 (88,2\%) dan 1-2 (72,7\%). Dari 95 subjek yang diimunisasi campak 1 kali, 76 (80\%) memiliki kadar antibodi protektif. Sementara dari 50 subjek yang diimunisasi campak 2 kali, 49 (98\%) memiliki kadar antibodi protektif (Tabel 4).

\section{Pembahasan}

Sebagian besar subjek $(86,2 \%)$ memiliki antibodi campak dengan kadar protektif. Antibodi campak dengan kadar protektif yang timbul pasca imunisasi dipengaruhi oleh beberapa hal, antara lain, kadar antibodi campak dari ibu menurun, kematangan imunologis, dosis vaksin, dan strain virus dalam vaksin. ${ }^{16}$ Beberapa faktor biologi menentukan efektivitas dan imunogenisitas vaksin campak. Imaturitas sistem imun yang menghambat terbentuknya antibodi protektif, antara lain, jumlah sel B yang terbatas dan mekanisme presentasi antigen dan sel Th yang tidak efisien. ${ }^{16}$ Bayi usia muda ( $\leq 6$ bulan) tidak memiliki kadar antibodi yang cukup tinggi setelah imunisasi campak dengan vaksin virus campak yang dilemahkan, bahkan pada kondisi tidak terdapatnya antibodi maternal. Respon pembentukan IgG lebih rendah daripada dewasa dan aviditas antibodi menurun. Respon imun yang tidak efisien ini dapat disebabkan gangguan interaksi antara sel limfosit $\mathrm{T}$ dan sel yang mempresentasikan antigen. ${ }^{15}$

Sebagian besar subjek $(51,7 \%)$ mendapatkan suntik imunisasi campak di deltoid dibanding paha anterolateral. Kepustakaan menyebutkan bahwa paha 
anterolateral adalah bagian tubuh yang dianjurkan untuk imunisasi pada bayi dan anak usia di bawah 12 bulan. ${ }^{17}$ Sementara daerah deltoid adalah alternatif untuk imunisasi pada anak yang lebih besar (telah dapat berjalan) dan orang dewasa. Daerah paha anterolateral yang terdiri atas otot vastus lateralis direkomendasikan sebagai tempat penyuntikan sebagian besar vaksin untuk bayi dan anak usia di bawah 12 bulan karena cukup tebal untuk menyerap suntikan secara adekuat dibanding daerah deltoid, menghindari lapisan lemak subkutan yang tebal pada paha bagian anterior, dan menghindari risiko kerusakan saraf ischiadika pada suntikan daerah gluteal. Berdasarkan hal tersebut maka penyuntikan vaksin campak pada anak usia di atas 12 bulan dapat diberikan di daerah deltoid. Tidak ada kepustakaan yang membahas mengenai perbedaan respon imun yang terjadi apabila vaksin campak disuntikkan di paha anterolateral dibanding deltoid. Hal terpenting adalah penyuntikan dilakukan secara subkutan karena pada daerah tersebut terdapat banyak jaringan limfoid sehingga respon imun yang dihasilkan lebih adekuat. ${ }^{17}$

Sebagian besar subjek (75,9\%) diimunisasi campak pertama saat usia 9 bulan dan kedua usia 2 tahun (44\%). Usia saat imunisasi mempunyai pengaruh yang penting terhadap respon imun yang timbul. Usia optimal untuk imunisasi campak ditentukan oleh peningkatan laju serokonversi pasca imunisasi campak yang dipengaruhi usia saat imunisasi dan usia rata-rata terjadinya infeksi. ${ }^{15}$

Berdasarkan teori imunogenisitas vaksin campak, proporsi anak yang berespon dengan membentuk antibodi protektif terhadap campak adalah 89,6\% apabila diimunisasi campak pada usia 8-9 bulan, 92,2\% pada usia $9-10$ bulan, dan 99\% pada usia 1112 bulan. Hal ini sesuai dengan teori maturitas sistem imun yang telah dijelaskan sebelumnya. ${ }^{16}$ Respon antibodi terhadap vaksin campak meningkat seiring usia sampai dengan usia sekitar 15 bulan karena antibodi campak yang berasal dari ibu bersifat inhibisi telah hilang dan sistem imun telah matang.

Antibodi campak dari ibu bersifat inhibisi karena menghambat replikasi virus yang dilemahkan dalam vaksin yang dibutuhkan untuk menimbulkan respon imun. Aviditas antibodi juga merupakan karakteristik penting dari suatu respon antibodi yang matang dan menggambarkan seberapa kuat ikatan antibodi terhadap antigen virus campak. Respon antibodi dengan aviditas tinggi yang muncul meningkatkan imunitas protektif terhadap campak. Aviditas antibodi terhadap virus campak yang dilemahkan dalam vaksin campak biasanya lebih rendah pada anak yang diimunisasi pada usia 6 atau 9 bulan dibanding anak yang diimunisasi pada usia 12 bulan. ${ }^{15}$

Berdasarkan hal tersebut, pemberian imunisasi campak dosis pertama akan lebih efisien dalam membentuk antibodi hingga mencapai kadar protektif apabila diberikan pada usia 12 bulan. Namun demikian, pemberian imunisasi campak dosis pertama pada usia 9 bulan tidak ada salahnya dan sesuai dengan rekomendasi WHO mengingat Indonesia merupakan salah satu negara dengan transmisi campak yang tinggi. ${ }^{12}$ Pada daerah dengan transmisi virus campak yang tinggi, usia rata-rata terkena infeksi adalah usia muda sehingga strategi optimal adalah memberikan imunisasi campak pada usia semuda mungkin, yaitu usia 9 bulan. Sebaliknya pada daerah dengan transmisi virus campak yang rendah, usia pemberian imunisasi campak pertama dapat dimulai pada usia 12 bulan atau lebih. ${ }^{15}$

Pada penelitian ini terdapat hubungan antara frekuensi imunisasi campak dengan kadar antibodi protektif yang timbul. Individu yang diimunisasi campak lebih dari 1 kali memiliki kemungkinan 1,2 kali lebih besar untuk mencapai kadar antibodi protektif terhadap campak dibanding individu yang hanya diimunisasi 1 kali. Dasar imunologi pemberian imunisasi campak ke-2 adalah untuk mengimunisasi anak yang gagal berespon terhadap imunisasi pertama dan mengimunisasi mereka yang tidak pernah diimunisasi campak pertama. Respon imun terhadap re-vaksinasi bergantung pada adekuat atau tidaknya respon terhadap vaksin campak dosis pertama. Ketika vaksin campak dosis ke-2 diberikan pada anak usia di atas 1 tahun yang gagal mencapai kadar antibodi protektif pasca pemberian dosis pertama maka sebagian besar akan mencapai kadar antibodi protektif. ${ }^{15}$

\section{Kesimpulan}

Proporsi anak usia 1-4 tahun yang mendapatkan imunisasi campak 1 kali dan memiliki antibodi campak mencapai kadar protektif $80 \%$ dengan median kadar antibodi $733,5 \mathrm{mIU} / \mathrm{ml}$. Proporsi yang mendapatkan imunisasi campak 2 kali dan memiliki antibodi campak mencapai kadar protektif 98\% dengan median kadar 
antibodi $885 \mathrm{mIU} / \mathrm{ml}$. Pemberian imunisasi campak 2 kali meningkatkan timbulnya antibodi campak yang mencapai kadar protektif 1,2 kali dibanding pemberian imunisasi campak 1 kali.

\section{Daftar pustaka}

1. World Health Organization. Measles. Diakses tanggal 1 Agustus 2011. Diunduh dari: http://www.who.int/ immunization/diseases/measles/en/.

2. World Health Organization. Update on measles in Europe 2011. Diakses tanggal 15 Agustus 2011.Diunduh dari: http://www.euro.who.int/_datalassets/pdf_file/0003/217164/ OutbreakGuidelines-updated.pdf.

3. Kementerian Kesehatan Republik Indonesia. Kampanye imunisasi campak di Aceh, Sumatera Utara, Maluku Utara. Diakses tanggal 1 Agustus 2011. Diunduh dari: http://www. depkes. go.id/pdf.php?id=379.

4. Kementerian Kesehatan Republik Indonesia. Imunisasi efektif menekan angka kesakitan dan kematian bayi. Diakses tanggal 1 Agustus 2011. Diunduh dari: http://www.depkes.go.id/article/ print/1239/imunisasi-efektif-menekan-angka-kesakitan-dankematian-bayi.html.

5. Kementerian Kesehatan Republik Indonesia. Profil kesehatan Indonesia 2006. Diakses tanggal 10 September 2011. Diunduh dari: www.depkes.go.id/download.php?./profil-kesehatanindonesialprofil-kesehatan-indo.

6. Direktorat Jenderal Pengendalian Penyakit dan Penyehatan Lingkungan. Profil Pengendalian Penyakit dan Penyehatan Lingkungan tahun 2012. Diakses tanggal 12 September 2014. Diunduh dari: www.tbindonesia.or.id/pdf/profilpppl2012130917032535-phpapp02.pdf.

7. Badan penelitian dan pengembangan kesehatan departemen kesehatan RI. Laporan nasional riset kesehatan dasar (Riskesdas) tahun 2010. Diakses tanggal 10 September 2011. Diunduh dari: http://www.diskes.baliprov.go.id/fles/subdomain/ diskes/Januari\%202015/RISKESDAS\%202010.pdf.

8. Badan penelitian dan pengembangan kesehatan departemen kesehatan RI. Laporan nasional riset kesehatan dasar
(Riskesdas) tahun 2013. Diakses tanggal 3 Juni 2014. Diunduh dari: http://www.depkes.go.id/resources/download/general/ Hasil\%20Riskesdas\%202013.pdf.

9. Kementerian Kesehatan Republik Indonesia. Kemkes targetkan tahun 2014 seluruh desa/kelurahan 100\% UCI. Diakses tanggal 10 September 2011. Diunduh dari: http://www.depkes. go.id/development/siteljkn/index.php? cid $=1106$ o id $=$ kemkestergetkan-tahun-2014--seluruh-desa/kelurahan-100\%-uci.html.

10. Kementerian Kesehatan Republik Indonesia. Petunjuk Teknis Kampanye Imunisasi Campak Tahun 2006. Ditjen PP\&PL Depkes RI Jakarta.

11. Kementerian Kesehatan Republik Indonesia. Imunisasi tambahan polio dan campak digelar di 17 provinsi. Diakses tanggal 18 September 2013. Diunduh dari: http://www. depkes.go.idlarticle/print/1696/menkes-canangkan-kampanyeimunisasi-tambahan-campak-dan-polio.html.

12. World Health Organization. A guide to introducing a second dose of measles vaccine into routine immunization schedules. Geneva: WHO; 2013.

13. Kementerian Kesehatan Republik Indonesia. Peraturan Menteri Kesehatan No 42 Tahun 2013 tentang Penyelenggaraan Imunisasi. Diakses tanggal 23 Juli 2014. Diunduh dari: http:// pppl.depkes.go.id/_asset__regulasi/92_PMK\%20No.\%2042\%20 ttg\%20Penyelenggaraan\%20Imunisasi.pdf.

14. Ikatan Dokter Anak Indonesia. Jadwal imunisasi anak usia 0 18 tahun. Rekomendasi Ikatan Dokter Anak Indonesia (IDAI) 2014. Diakses tanggal 3 Mei 2014. Diunduh dari: http://www. idai.or.id/wp-content/uploads/2014/04/Jadwal-Imunisasi-2014lanscape-Final.pdf.

15. Moss WJ, Scott S. WHO Immunological Basis for Immunization Series, Module xx: Measles, 26 August 2008. Diakses tanggal 8 September 2011. Diunduh dari: http://www.who.int/immunization/sage/Module_on_Measles_ Immunology_26Aug08.pdf.

16. Moss WJ, Strebel P. Biological feasibility of measles eradication. J Infect Dis 2011;204:47-53.

17. Salimo H, Soegijanto S. Campak. Dalam: Ranuh IGN, Suyitno H, Hadinegoro SRS, Kartasasmita CB, Ismoedijanto, Soedjatmiko, penyunting. Buku Pedoman Imunisasi di Indonesia. Edisi ke-5. Jakarta: Badan Penerbit IDAI; 2014.h.329-33. 